DOI: $10.20287 /$ doc.d24.ac01

\title{
Reflexões sobre o processo criativo no documentário $A$ caméra-stylo de Vicente F. Cecim
}

\author{
Alexandra Castro Conceição* \\ Caméra-stylo de Vicente F. Cecim (Brasil, 2018, 76 min.) \\ Direção, Pesquisa e Produção: Alexandra Castro \\ Fotografia: Lériton Brito, Gilberto Mendonça e Cezar Moraes. \\ Montagem: Eliezer França \\ Som Direto: Lériton Brito e Kemuel Carvalheira
}

\section{Sobre o meu processo criativo}

Penso ser difícil falar sobre o meu processo criativo, por não saber exatamente como este surge. Ele não surge de uma epifania, de um momento em que recebo forças enigmáticas. Decido realizar alguma coisa, que pode ser um vídeo, um roteiro, um argumento, por exemplo, e passo a planejá-lo. Sem grandes elucubrações, apenas penso, imagino e tento ser realista e criativa ao mesmo tempo, por reconhecer as limitações que encontro no decorrer do processo.

Minha formação acadêmica como administradora e advogada conferem uma característica mais objetiva ao meu processo e apesar de parecer uma desvantagem a uma realizadora de arte a alguns, considero uma característica pertinente, vez que não acredito que a obra de arte só pode ser concebida por meio da epifania, mas como exercício continuo. Por esse motivo observo certas semelhanças com meu processo e Eduardo Coutinho, realizador que usarei como referência, também usarei referências de Dziga Vertov, os escritos de Jacques Aumont, Marcius Freire, Ismail Xavier e Bill Nichols.

Assim como Coutinho (2004: 8) não idealizo o artista, muito menos a mim, e cinema não é feito apenas de inspiração, também é fruto de muito "trabalho árduo, interação com o mundo e reflexão".

Coutinho dissolve os mitos em torno da "arte"do documentário. Recusa-se a lhe atribuir uma aura ou identificar essa prática ao espírito iluminado de poucos privilegiados. Descomplica o processo de filmagem e insiste na ideia

\footnotetext{
* Doutoranda. Universidade Estadual de Campinas - UNICAMP, Instituto de Artes, Programa de Pós-Graduação em Multimeios. 13083-854, Campinas, Brasil.

E-mail: alexandracastro_ac@yahoo.com.br
} 
de que é possível filmar e experimentar com pouco dinheiro, a partir de um desejo comum de realizar um filme e fazendo uso de tecnologias leves e de baixo custo. Seus documentários nos mostram isso: são filmes que dão vontade de fazer cinema. Talvez seja esse um dos motivos para que esse cineasta que começou a dirigir nos anos 60 atraia hoje tantos jovens interessados no documentário. Suas imagens e falas são fecundas e libertadoras. Abrem um campo de possibilidades e afirmam o cinema como arte cada vez mais impura, aberta ao mundo, à diferença, ao imponderável ao presente. (Lins, 2004: 8, 9). .

\section{Como tudo começou}

A proposta inicial de minha pesquisa era sobre a representatividade do imaginário amazônico e o cinema paraense, mas eu não tinha, ainda, escolhido o objeto da pesquisa. Ele surgiu por conta de uma postagem em uma rede social, escolhi o Vicente F. Cecim quase por acaso, ao tomar conhecimento de uma mostra de filmes dele no Cine Olympia. Nesse instante, percebi o quanto era importante falar sobre ele, pois muita gente desconhecia o fato dele também ser cineasta, além de ser escritor.

Decidi falar sobre as suas obras cinematográficas e as limitei aos seus primeiros cinco filmes, realizados na década de 70, em película, com câmera Super 8. São eles: Matadouro (Vicente F. Cecim, 1975); Permanência (Vicente F. Cecim, 1976); Sombras (Vicente F. Cecim, 1977); Malditos Mendigos (Vicente F. Cecim, 1978) e Rumores (Vicente F. Cecim, 1979).

Quando comecei a realizar a pesquisa sobre o meu projeto, iniciei pelo imaginário, li especialmente Gilbert Durand e Michel Maffesoli, que me ajudaram a compreender o imaginário, e João de Jesus Paes Loureiro, que me ajudou com relação ao imaginário amazônico. Decidi também conversar com Paes Loureiro, uma vez que ele é paraense e havia sido meu professor, tanto na graduação, como no mestrado, o convidei para ser um dos entrevistados para o documentário que iria fazer para o meu projeto, e ele aceitou o convite.

Decidi fazer não apenas o trabalho escrito, como também um vídeo documentário sobre o meu objeto, uma vez que me permitiam trabalhar com a poética, e me sinto muito a vontade filmando, gosto de filmar, e se me permitem fazer isso, eu escolho fazê-lo. Mas o que é um documentário e como eu o faria?

Segundo Nichols os documentários tratam da realidade, de pessoas reais e de histórias sobre o que realmente aconteceu. O documentário que decidi realizar trata sobre uma pessoa real: Vicente F. Cecim, que falaria sobre suas criações da década de 70, seus pensamentos, suas experiências, suas vivências e sua visão de mundo, relacionadas ao seu modo de fazer cinema. 
Uma afirmação mais precisa seria "documentários tratam de pessoas reais que não desempenham papeis". Em vez disso, elas "representam" ou apresentam a si mesmas. Recorrem a experiências anteriores e hábitos para serem elas mesmas diante da câmera. Podem estar totalmente cientes da presença da câmera, com a qual, em entrevistas e outras interações, comunicam-se diretamente. (Nichols, 2016: 31). .

Além disso,

Um documentário é mais que comprovação: é também uma maneira particular de ver o mundo, de fazer propostas sobre ele ou de oferecer pontos de vista sobre ele. Nesse sentido, ele é uma maneira de interpretar o mundo. Ele usa a comprovação para fazer isso. (Nichols, 2016: 55). .

A comprovação do documentário é feita por meio da captação de som e imagem que passam a ser registros, documentos. Realizar o documentário sobre Cecim é fornecer além de conhecimento sobre ele, é oferecer pontos de vista sobre o artista, sobre alguém que o público desconhece a história do seu cinema, é fornecer ao público um registro da história dele, antes que essa se perca no tempo.

Também cabe lembrar que esse documentário parte de uma pesquisa acadêmica, e para Freire aliar imagens a pesquisa é potencializar os seus resultados. Ademais, não se tratava apenas de pegar um câmera e entrevistar as pessoas, pois o documentário que eu objetivava realizar não tinha apenas a intenção de fundamentar uma pesquisa, mas também de ser uma obra cinematográfica, de usar o potencial artístico desses registros.

Até aquele momento, apenas de pesquisa, era o imaginário que permeava o meu projeto, contudo eu deveria representar o imaginário amazônico nas obras de Vicente Cecim, mas neste momento eu já sabia que isso seria difícil, especialmente porque as referências que tenho sobre o assunto tem uma visão especifica, acadêmica, e que de imediato eu percebia que não concordariam com o meu objeto. Porém, mesmo com essa questão segui a diante e continuei a pesquisa.

Segundo Claudine de France, existe, na realização de qualquer documentário sobre o Outro, uma prática que não aparece obrigatoriamente na tela, mas que vai determinar, de forma incontornável, o resultado final do filme: a "inserção". Tal prática faz parte de uma etapa no processo de realização por ela denominada de "fase preliminar". No tipo de filme a que chama de "exposição" e que define o documentário clássico, essa fase se traduz na aproximação do cineasta às pessoas observadas com o intuito de aprender sobre elas aquilo de que precisa para a conformação de seu filme. Nessa fase, o cineasta se serve de recursos como a identificação de informantes, a entrevista e a observação imediata - geralmente acompanhada de anotações - de elementos passíveis de serem gravados; em suma, suas ações têm, quase sempre, como 
objetivo a prospecção dos elementos que vão dar forma ao seu roteiro, pois será este último que servirá de guias às filmagens. (Freire, 2011: 50). .

Assim como descrito por Claudine de France foi o que ocorreu durante a fase preliminar, a pré-produção do documentário, durante a pesquisa pude observar as dificuldades que enfrentaria, assim como tracei o percurso que executaria para realizá-lo. Diante dessas observações defini que faria apenas duas entrevistas: uma com o professor João de Jesus Paes Loureiro, que falaria sobre o imaginário, imaginário amazônico, sobre cinema paraense, e com o artista Vicente Cecim, meu objeto de estudo, que falaria também sobre imaginário, sobre suas obras, seu processo de produção e criação.

Mas, diferente do que Freire fala em seu livro que a partir de observações realizadas na fase pré-liminar se constrói um roteiro, eu não o escrevi. Nesse ponto minha ação se parece com a descrição feita do que ocorre com Coutinho, porque como se tratava de uma entrevista, eu estava aberta a todo tipo de mensagem, informação que eles quisessem me dar, e a partir disso construir o documentário.

O documentário que interessa não reflete nem representa a realidade, e muito menos se submete ao que foi estabelecido por um roteiro. Trata-se, antes, da produção de um acontecimento especificamente fílmico, que não preexiste à filmagem. Nas obras de Coutinho, o mundo não está pronto para ser filmado, mas em constante transformação, e ele irá intensificar essa mudança. O que não quer dizer que defenda uma filmagem sem princípios, sem limites, espontânea, "uma câmera na mão e uma ideia na cabeça"- muito pelo contrario. Seus filmes são frutos de muitas leituras e conversas, de intensa pesquisa e negociação; e também de inúmeros riscos, hesitações e receios. Em vez de roteiro, ele filma a partir de "dispositivos" - procedimentos de filmagem que elabora cada vez que se aproxima de um universo social. (Lins, 2004: 8). .

\section{Dispositivo}

Durante a leitura me deparei com o conceito de dispositivo que trata dos procedimentos de filmagem também referidos por Coutinho (2004: 102) como prisão, pois indicam "as formas de abordagem de um determinado universo", os quais eram para ele mais importantes do que o tema do filme, e deve ser criado antes do filme. O dispositivo pode ser "filmar só gente de costas", por exemplo.

Mas, e qual era o meu dispositivo para o meu documentário?

$\mathrm{O}$ meu dispositivo eram as perguntas nortedoras que faria para os meus entrevistados. Meu objetivo era de ouvir os entrevistados e a partir de suas falas conhecer e mostrar os seus pontos de vista, as suas experiências, as suas vivências, a forma como eles enxergavam a arte, o cinema, o mundo. Pois, "A 
vida de verdade não se conta: mostra-se, analisa-se e, finalmente, compreendese". (Aumont, 2012: 113).

Além disso, Aumont em seus escritos sobre o cinema de Vertov traz o que eu buscava na realização do documentário, que era mostrar o artista e sua visão de mundo.

O cinema serve, portanto, antes de mais nada, para mostrar as pessoas de verdade, da vida de verdade e não atores que encenam uma paródia da vida de verdade, nem mesmo pessoas de verdade que desempenham papeis em um roteiro". (Aumont, 2012: 113). .

As perguntas norteadoras indicam o assunto sobre o qual gostaria que as pessoas falassem, e a partir dos comentários delas eu criarei o documentário. Essas perguntas são apenas diretrizes, porque muitas vezes o entrevistado acaba dando respostas mais abrangentes e contado coisas que o meu questionamento não abordava de início. Não são questionamentos fechados, mas que propiciam o início de uma conversa, a qual o entrevistado estende até o ponto em que acha interessante eu ter conhecimento sobre a história que ele está me contando.

\section{Entrevistas}

Segundo Consuelo (2004: 147) "Perguntar é efetivamente uma tarefa difícil, seja em uma pesquisa, em reportagens ou mesmo no cotidiano" e nos documentários de Coutinho é difícil e central, assim como no documentário que eu estava construindo.

Conversar, orientar uma conversa, "desprogramar", atrapalhar o menos possível, mas intervir de alguma forma, estas são questões que não se resolvem de "uma vez por todas". Não há como fazer um "manual"das perguntas corretas. A cada vez que acontece uma entrevista, surgem resoluções diferentes, com seus erros e acertos. Estamos sempre ameaçados "sob o risco do real". Vários elementos estão em jogo. [...] pelas antecipações que fazemos na nossa própria fala do que achamos que pensa e vai fazer o nosso interlocutor. Há, como também vimos, as "expressões de si" pré-constituídas pela mídia, assim como a tentativa de captar na própria pergunta os aspectos implícitos que apontam para a resposta "certa", de modo a conquistar os segundos de glória. Também ocorrem as respostas inventadas no momento da entrevista, "fresquinhas", e não obstante fabricadas para agradar ao cineasta. (Lins, 2004: 147). .

Marquei com o Professor Paes Loureiro para filmá-lo, eu e minha equipe fomos para o local da filmagem escolhido por ele. Para a entrevista com ele as perguntas norteadoras eram de caráter mais geral, sobre imaginário, a arte e o cinema. Fiz perguntas chaves, de coisas que tinha dúvidas e gostaria que o professor discorresse a respeito. Sem intervenções da minha parte o profes- 
sor decidiu ater suas falas sobre o imaginário, imaginário amazônico, arte e o cinema paraense. Ele não adentrou suas falas as obras de Vicente Cecim, ele preferiu dar ênfase a uma visão geral.

Durante a realização do documentário não procuro orientar, fazer intervenções nas falas ou interromper os pensamentos, quero atrapalhar o mínimo possível, quero ouvir, e espero que a pessoa me dê informações preciosas e que a partir delas eu terei o meu documentário. Sem que o induza a falar o que gostaria de ouvir. Espero que ela me surpreenda. Porque o objetivo é que eles se apresentem como são e não como personagens criados pelo diretor. Para Nichols:

No caso da não ficção [...] As "pessoas" são tratadas como atores sociais, não como atores profissionais. Os atores sociais continuam a levar a vida mais ou menos como fariam sem a presença da câmera. Continuam a ser participantes culturais, não artistas teatrais. Seu valor para o cineasta consiste não no que exige uma relação contratual, mas no que a própria vida dessas pessoas incorpora. Seu valor reside não nas formas como disfarçam ou transformam comportamento e personalidade habituais, mas nas formas como comportamento e personalidade habituais servem às necessidades do cineasta. (Nichols, 2016: 64). .

Mas, Consuelo nos alerta para um aspecto dos atores sociais que pode se tornar uma armadilha para os realizadores e deve ser evitado, a não ser que seja este o intuito do cineasta.

Essa pessoa que aparentemente não sabe nada tem uma extraordinária intuição do que você quer. Se o entrevistado quiser respostas de protesto, de "esquerda", ele vai ter; se quiser o contrário, vai ter também. Essa é uma das coisas mais importantes a se quebrar, não sugerir ao outro o que você quer ouvir. O que quer dizer respeitar uma pessoa? É respeitar a sua singularidade, seja ela uma escrava que ama a servidão, seja ela uma escrava que odeia a servidão. Muitos documentaristas só ouvem as pessoas que dão respostas de acordo com suas intenções, o que gera um acúmulo de respostas do mesmo tipo, previsíveis, e que são aquilo que o diretor quer ouvir. (Lins, 2004: 147).

Estas passagens, de Nichols e Consuelo, me remetem aos escritos sobre o cinema de Vertov e seu kinoglaz (Cine-Olho), que negava a:

Tomada de improviso "pela tomada de improviso", mas para mostrar as pessoas sem máscara, sem maquilagem, fixá-las no momento em que não estão representando, ler seus pensamentos desnudados pela câmera. (Xavier, 1983: 262). .

Ou seja, é como se o realizador tivesse que pegar a pessoa de surpresa e tirar dela a ideia limpa que ela tem, ainda não impregnada daquilo que ela acha que o diretor quer ouvir, daquilo que ela considera que cabe a aquele trabalho 
fílmico e que assim está ajudando o realizador, mas captar o seu pensamento livre, sem máscara.

Após a gravação com o professor Paes Loureiro, marquei com o Vicente Cecim para gravarmos a sua participação no documentário. Neste momento, já sabia que a concepção de imaginário de Cecim seria diferente do que havia estudado, pesquisado nos livros de Durand, Maffesoli e Paes Loureiro. Porém, mesmo assim eu queria saber quais eram as concepções e ideias de Cecim sobre o assunto, além de obter informações sobre seu percurso artístico e sobre seus filmes nos anos 70 .

Foram mais de 2 horas de gravação de falas do Cecim. E eu não conseguiria descrever como ele raciocina, ou faz ligações entre assuntos para formar os seus conceitos, ou como a partir do que ele forma suas ideias. Não conseguiria generalizá-lo, ele é singular. Mas, é dessa forma que ele se torna um ser mais "atraente", o qual você tem mais curiosidade em ouvi-lo. Ele é o meu "personagem"central do documentário e é ele quem me ajudará a criar a "história" que irei contar. E assim como dito por Consuelo (2004: 5), ela acontece face a face com seu personagem, se constrói uma história a dois, em que o desfecho não é conhecido de forma antecipada. Porque mesmo que o filme dependa do que é narrado pelo outro, é o diretor quem tem a decisão final sobre a obra, é ele quem decide o que e como será incluído no filme. Como afirmado por Nichols, porque normalmente os documentaristas

Obtêm uma cessão de direitos de todas as pessoas que filmam. Essa cessão dá ao cineasta poder total de decisão. O indivíduo renuncia a todo e qualquer controle sobre o uso da imagem e, portanto, sobre o resultado. (Nichols, 2016: $65)$. .

Após a gravação com Cecim, chegou o momento em que eu deveria decidir sobre o meu trabalho, se ele seria permeado pelo imaginário amazônico, ou não. E decidi abrir mão do imaginário e focar nas obras de Vicente Cecim, nos anos 70, e analisá-las quanto a sua linguagem e estética.

Segundo Coutinho "Você comete erros toda hora e tem que ouvir os outros quando dizem algo que revela coisas. É preciso radicalizar no próprio jogo". (Coutinho, E. 16/03/2016 Apud Lins, 2004: 128) E assim, eu fiz, mudei o meu projeto, mas de forma a aproveitar o que já havia filmado. Tomei a decisão de mudar de rumo e não me arrependo. É necessário aprender a identificar quando algo se revela a você.

Mantive a participação do Professor Paes Loureiro no documentário e usei a sua fala como completo a de Vicente Cecim, vez que as falas do Professor são de caráter acadêmico, e as de Cecim se fundamentam no empirismo, em suas vivências. As ideias que ambos apresentam são complementares e não 
divergentes. E assim como Coutinho, não tenho a pretensão de estereotipar ninguém, mas mostrar a diversidade de pensamentos.

Em momento algum há generalização, classificação ou palavras concludentes sobre os personagens. As pessoas não são exibidas como exemplos de nada. Não são psicossociais - "o morador de favela", "o catador de lixo", "o crente", "o classe média", "o operário" -, não fazem parte de uma estatística, não justificam nem provam uma ideia central, não são vistas como parte de um todo. Os depoimentos muitas vezes se contradizem, apontando para um mundo heterogêneo, com direções múltiplas. Mas é justamente essa diversidade que "abre"os personagens uns aos outros, sem que uma verdade final sobre eles seja estabelecida. (Lins, 2004: 71). .

É necessário que haja respeito pela fala do outro, você não precisa acreditar no que ele está dizendo, mas buscar compreender o motivo pelo qual ele está dizendo isso. Um exemplo é quando Eduardo Coutinho filmava Theodorico, Imperador do sertão (Eduardo Coutinho, 1978):

Filmar sem forçar o traço, sem caricaturar, intervindo o menos possível. O contato entre o diretor e o major é sempre cordial. Coutinho jamais o coloca "contra a parede", como modo de enfatizar para o espectador que o que está sendo dito é um despautério e que o Theodorico é o diabo do sertão. O que interessa ao cineasta não é definir o personagem à revelia dele, nem tratá-lo como um fenômeno da realidade, dotado de rígidos traços típico-sociais. O que interessa é a visão de mundo do personagem, o ponto de vista específico que ele tem sobre o mundo e sobre si mesmo. É o próprio major que, nos diálogos com Coutinho, com seus empregados e amigos, revela e fundamenta sua razão de ser, sem que o filme precise expressar simpatia ou antipatia, acordo ou desacordo, nem fazer avaliações conclusivas sobre o que está sendo dito. (Lins, 2004: 22 e 23). .

E assim como Coutinho, prefiro dar as ferramentas para que o próprio personagem demonstre quem é, a partir de seus pensamentos, das suas vivências, experiências, estudos, a partir da consciência a qual ele tem de si mesmo. Quando apontamos a câmera para uma pessoa e a filmamos ela tenta nos mostrar o melhor dela, tenta nos deixar curiosos pela história que ela conta, ela quer nos atrair, quer mostrar o seu ponto de vista e justifica-lo, assim como justificar as suas ações, ela fala em prol dela mesma. E Consuelo explicita isso muito bem ao dizer que o entrevistado

Aproveita ricamente a ocasião que Coutinho lhe oferece. Constrói o seu autoretrato, se inventa de alguma forma a partir do que ela gostaria de ser, do que talvez seja e do que pensa que o diretor gostaria que ela fosse. (Lins, 2004: 110). .

As vezes é difícil ter essa visão de manter a mente aberta ao que o outro diz, sem que coloquemos nosso juízo de valor ou poder de crítica sobre a opinião do outro. Mas, como pergunta Consuelo (2004: 21): "e como fazer isso? Como 
superar os limites da nossa "natureza"e entrar na "natureza"alheia? Como lidar com a imagem do outro, quando esse outro é um personagem de cuja visão de mundo não compartilhamos?". Ainda segundo Consuelo (2004: 108) o diretor deve "tentar compreender o imaginário do outro, mas sem aderir a ele", sem julgá-lo ou avaliá-lo, sem considerar que o o que está sendo falado é um delírio, porque "o que o outro diz é sagrado".

Procuro não impor a visão de mundo que tenho e busco compreender o que o outro me diz, tentando não realizar críticas as suas opiniões, mas compreendê-las. O ouço com curiosidade, sem fazer e expor minhas conclusões, porque o quero livre, quero que ele se sinta bem, confortável, mesmo diante da câmera, para expor as suas ideias, seus pensamentos, suas experiências. Para Vertov essa é a "possibilidade de tornar visível o invisível, de iluminar a escuridão, de desmascarar o que está desmascarado, de transformar o que é encenado em não encenado, de fazer da mentira a verdade". (Xavier, 1983: 262).

Durante a entrevista Cecim traçava em sua mente tudo o que iria falar. Ele falava a medida que as coisas vinham a sua mente, ele imaginava suas respostas e no meio delas surgiam novos apontamentos, novas ideias e ele nos as oferecia, dividia conosco. As vezes ao fazer uma pergunta ele começava a resposta criticando o meu questionamento, porque eu tinha caracterizado a sua obra, ele me "alfinetava"e demonstrava seus motivos para que não aceitasse aquele pré-julgamento. Além disso, mesmo que eu não fizesse várias intervenções em suas falas eu sabia que eles estavam falando comigo, para mim e para a equipe também, e isto tem que ficar claro, que há um interesse mutuo ali. Como é defendido por Coutinho:

"Se eu digo que o meu desejo é só escutar, não há filme, não é assim. Se há um lado passivo na interlocução, acabou. Os dois lados devem estar ativos", diz ele. Essa é uma escuta que intensifica o desejo de se expressar de quem está diante da câmera." (Coutinho, E. 16/03/2016 apud Lins, 2004: 110). .

Além disso, segundo Nichols:

Nos documentários, encontramos histórias e propostas, evocações ou descrições, que nos permitem ver o mundo de uma nova maneira. A capacidade da imagem fotográfica de reproduzir a aparência do que está diante da câmera, sua característica indicial, força-nos a acreditar que é a própria realidade que é representada diante de nós, ao passo que a história ou proposta apresenta uma maneira distinta de olhar essa realidade. (Nichols, 2016: 62). .

É por meio do que o outro diz que observaremos a história que está sendo posta diante de nós, em frente as câmeras, e a partir dela que se construirá a obra fílmica. 


\section{Corpo do Documentário}

E assim o documentário começa a ganhar corpo, começa a se formar, eu começo a enxergar o potencial do material que terei em mãos, assim como se terei o resultado esperado satisfatório, ou não, e caso não tenha, será necessário tomar outro caminho até que encontre "algo" que eu queira contar. Felizmente, isso não aconteceu neste documentário, porque enquanto filmava eu sabia quando conseguia algo importante: um depoimento que traz a tona o sentimento do entrevistado, a sua opinião verdadeira, e percebia que estava no caminho certo. Há uma passagem do livro de Consuelo sobre Coutinho, no capítulo sobre O Cabra marcado para morrer (Eduardo Coutinho, 1984), que retrata exatamente esta sensação:

Filmei a Elizabeth em três dias, dois dias e meio ... Nós íamos fazer a primeira parte na Paraíba e depois a parte de Pernambuco. Mas, quando acabei de filmar a Elizabeth, já senti o filme com tal vida, que decidi: 'Vamos direto para Pernambuco. Vamos liquidar Galiléia, porque se for bem na Galiléia, o filme está pronto'. Daí nós fomos para Pernambuco e fizemos aquela cena da projeção ... Enquanto estávamos preparando as coisas, o João Virgínio deu aquele grande depoimento sobre a tortura ... A projeção foi complicada, porque tivemos de buscar os atores que moravam longe, e foram todos. Foi maravilhoso ... Naquela noite eu já sabia que tinha o filme, tinha certeza, um filme fortíssimo, ... tinha certeza absoluta de que o filme era bom.” (Viany, A. 16/03/2016 apud Lins, 2004: 43). .

Mas, as vezes estamos com o trabalho em andamento e não sabemos exatamente o que iremos fazer, vamos recolhendo material, filmando muitas coisas, juntando imagens e entrevistas e só depois é que descobrimos o filme que iremos fazer, quando decupamos o material e percebemos que o filme está ali. Segundo Freire:

O que é o filme documentário se não "um tecido de citações [imagéticosonoras, nesse caso] saídas dos milhares de abrigos da cultura"? Seja como for, para costurar essas citações e fazer delas um tecido que produza sentido, uma condição é inelutável: o documentarista deve, antes de tudo, partilhar do mesmo espaço, ter os seus sentidos imergidos na mesma ambiência dos seres e das coisas que compõem que vai registrar. E, em assim fazendo, estará, de alguma forma, envolvido com todos esses elementos, o que faz de seu filme uma citação que o inclui. (Freire, 2011: 234). .

Além disso:

A partir de que critérios o cineasta mostra, sublinha, oculta os elementos que observa, uma vez que filmar significa escolher o quê, como e quando mostrar? ... Nunca é demais relembrar que existe uma dependência da mise en scène do cineasta em relação à auto-mise en scène das pessoas filmadas se o objetivo de seu registro está em descrever, restituir da maneira mais fiel possível, o desenrolar espaçotemporal da atividade filmada. Isso significa dizer que, 
nesse caso, a organização do espaço e do tempo fílmico, ou seja, a adoção de ângulos e enquadramentos, bem como a duração dos planos, está submetida ao continum espaçotemporal das pessoas filmadas e dele decorre. (Freire, 2011: 232). .

Mesmo que o realizador dependa dos atores sociais para construir a sua obra e mesmo que "perca" um pouco de sua autonomia por isso, ele estará presente em todas as etapas da produção e ele estará mais que incluído nela, ela será parte de quem ele é, do que ele acredita, da sua visão de mundo, logo fará parte da obra, assim como é dito por Freire. Não há como o diretor se separar de sua obra, dela ser vista em apartado.

Durante a decupagem das entrevistas sigo meus princípios e mantenho as vozes dos entrevistados, pois desejo que eles se reconheçam em suas palavras e em seus fundamentos. Mas, a partir das minhas escolhas, daquilo que quero mostrar, porque como defende Consuelo (2004: 49): "Esquece-se com excessiva facilidade que se trata de um filme, e que o diretor pode simplesmente cortar falas e imagens que o perturbam. Se são mantidas, é porque fazem parte da proposta do filme". Fazem parte do que o diretor pretende mostrar em seu filme. Tento manter uma pretendida imparcialidade, que apesar de utópica tem a ver com uma certa ética de trabalho. Contudo:

O equilíbrio é frágil, pois é preciso impedir tanto a cumplicidade moral entre cineasta e personagem quanto o desrespeito ao pensamento de quem foi escolhido para ser protagonista do filme. [...] A câmera é definitivamente um instrumento de poder que pertence a quem filma, dirige e monta. É possível prejudicar uma pessoa com um simples enquadramento ou manipular na montagem o que é dito. (Lins, 2004: 21/22). .

Para muitos espectadores os documentários "ferem"um pouco do que elas consideram como cinema, onde a imagem tem muito mais valor que a fala na maioria das vezes, e por isso se tornam menos atraentes aos espectadores, porém como dito por Coutinho:

O cinema é audiovisual há mais de 70 anos ... Essa posição contraria uma certa teoria do cinema e também uma ideia do senso comum que definem o cinema como arte feita essencialmente de imagens. Um pensamento estreito que não vê a complexidade da imagem e do som da palavra do outro, não vê "os silêncios, tropeços, ritmos, inflexões, retomadas diferenciadas do discurso. E gestos, franzir de lábios, de sobrancelhas, olhares, respirações, mexer de ombros, etc." (Lins, 2004: 111/112). .

Também sobre documentários, para Nichols eles:

Trabalham intensamente para extrair as histórias que trazemos para eles como forma de estabelecer relações, e não repulsa ou projeção. Essa é a base do princípio retórico central de tornar um filme convincente. Se um filme conseguir ativar nossas predisposições e aproveitar as emoções que já temos em 
relação a certos valores e crenças, isso pode aumentar seu poder afetivo. Os documentários podem apelar para a nossa curiosidade ou para nosso desejo de uma explicação sobre a política norte-americana em relação às guerras contra Vietnã, Granada, Haiti, Sérvia, Afeganistão ou Iraque, por exemplo. (Nichols, 2016: 112). .

Este documentário é composto quase $100 \%$ de falas, nós mais ouvimos que vemos imagens, até porque os cenários não foram construídos para os entrevistados, eles estão sentados diante as câmeras, ou seja, o fundo não tem função de composição, pode ajudar de forma implícita, mas não exerce essa função.

E além da captura da fala, temos a captura da expressão corporal do entrevistado pela imagem, isso é algo que me chama muita atenção quando filmo. E a expressão corporal de Vicente Cecim prende a nossa atenção. Enquanto fala, ele faz vários gestos, as vezes apenas de afirmação, para saber se estamos ali com ele, se estamos prestando atenção ao que ele diz, o que é muito importante para o interlocutor, sentir que há interesse pelo que ele conta. Para Coutinho:

Tão importante quanto a fala dos personagens são as expressões faciais e os movimentos do corpo. São "corpos falantes, gente com vísceras e imaginação", diz ele revelados pela palavra e pela imagem de quem está falando. (Coutinho, E. 16/03/2016 apud Lins, 2004: 111). .

E assim Coutinho me lembra que um filme não trata-se apenas da fala, mas de gestos, de silêncios, de olhares, de mudanças repentinas de pensamento ou da direção deles, e que estes são preciosos e expressam muito, e muitas vezes são por eles que compreendemos mais a pessoa do que quando apenas a ouvimos. Além disso, Para Nichols (2016: 78) o público entende que as pessoas que estão na obra, estão lá para serem examinadas e construídas e eles investigam não apenas as falas, como os seus gestos também. E esses personagens

Podem ser apresentadas como indivíduos plenos, bem acabados, com psicologias próprias e complexas [...] mas, com a mesma freqüência, parecem surgir diante de nós como exemplos ou ilustrações, manifestações de uma situação ou acontecimento que ocorreu no mundo. Pode parecer redutor ou enfraquecer, mas também pode ser extremamente convincente e eficaz. (Nichols, 2016: 78). .

Contudo, é importante lembrar que um documentário é um filme. E para Vertov não é "uma distração nem uma ferramenta do imaginário, mas uma ferramenta para ver o mundo tal como é realmente, isto é, como é útil e até necessário vê-lo". (Aumont, 2012: 20) Ou seja, o cinema não pode apenas ser considerado uma mera distração ou entretenimento, mesmo que seu objetivo 
principal seja esse, pois sua função social não é apenas esta, como defendido por Vertov. Pois:

Também para ele, se é preciso mostrar, antes de mais nada, deve-se aprender a ver (como mostrar o que não se sabe ver?) (...) O cineasta é aquele que aprende a ver, depressa e com exatidão; ora, para isso, não é necessário ver com seu olho, mas com sua câmera; é preciso confiar nesse super-olho e torná-lo autônomo: liberado do tempo e do espaço, o "cine-olho" vai nos oferecer sua percepção radicalmente nova, ao passo que a submissão a nossos órgãos naturais (e à nossa psicologia nativa) entrava o homem em seu vir a ser máquina, em seu vir a ser elétrico. (Aumont, 2012: 74). .

\section{O Documentário}

A minha proposta de direção do documentário foi bastante simples. Escolhi filmar com duas câmeras, uma com o plano mais aberto e a outra com o plano mais fechado, as duas fixas. Ambos aparecem sentados diante as câmeras. Escolhi não entrar em quadro, queria as atenções somente para eles e para o que falavam. Também não quis uma câmera na mão, não queria que ambos ficassem preocupados em saber onde a câmera estava focando e também não gostaria de ter imagens que chamam mais a atenção pelo movimento de câmera do que pelo discurso que está sendo captado. Na captura das imagens escolhi ser objetiva e deter o olhar no personagem sentado diante da câmera.

Também não darei explicações, não pegarei o espectador pela mão e o conduzirei no filme, the explicando tudo e fazendo com que ele tenha as mesmas conclusões que eu tenho. Não, eu desejo que ele faça essa "viagem"sozinho e faça as suas análises e tire as suas próprias conclusões. O documentário não terá ferramentas educativas ou elucidativas. Até porque como diz Coutinho: "a explicação é sempre insuficiente. Ou ela é demais e mata o filme, ou é de menos e não adianta. Ela nunca é justa". (Coutinho, E. 16/03/2016 apud Lins, 2004: 80).

O documentário que apresentei em minha defesa do Mestrado em Artes, em julho de 2016, na Universidade Federal do Pará, teve a duração de 46 minutos, contava com apenas duas entrevistas, a do artista objeto de minha pesquisa: Vicente F. Cecim e a do Prof. João de Jesus Paes Loureiro, foi todo filmado com 2 câmeras DSLR, a trilha musical utilizada foi a música Uirapuru do Maestro Waldemar Henrique. A montagem foi feita a partir da justaposição de partes da entrevista de Cecim, com sua fala mais informal, com a fala de Paes Loureiro, mais acadêmica, que complementava os dizeres de Cecim. E durante o processo de montagem do documentário fui surpreendida, pois percebi que a locação escolhida para a entrevista do Cecim, que antes não possuía função de composição, passa a compor a cena, pois Cecim não apenas fala conosco, a 
equipe, mas também interage com o fundo, com o extra-campo, e aquilo que antes não tinha essa função passa a potencializar e complementar a fala do entrevistado. Além disso, as falas de ambos eram precedidas por títulos, que introduziam os assuntos aos espectadores, uma forma de apresentar e de tornar os temas debatidos mais compreensíveis.

Contudo, após a defesa decidi dar continuidade ao meu processo de construção do documentário, uma vez que avaliei que ele estava muito acadêmico e eu não queria que ele tivesse essa "cara". Então, reuni a minha equipe e decidimos transforma-lo de um média para um longa-metragem. As modificações foram de caráter estético e de linguagem, decidimos realizar mais entrevistas, tornar a montagem menos acadêmica, acrescentando imagens de arquivos e inserindo transições de imagens que fizessem referências ao experimentalismo do artista, objeto do documentário, assim como mudar a trilha musical, retirando a música de Waldemar Henrique e colocando uma trilha original com características de música experimental, tomadas estas decisões voltamos a campo.

Realizei mais duas entrevistas, uma com o crítico de cinema Marco Antonio Moreira conhecedor e testemunha das obras de Cecim e com o pesquisador Felipe Pamplona, o qual conheceu as obras de Cecim já nos anos 2000, ambos falaram sobre o artista e sobre os filmes dele, contudo cada um com sua visão particular. Marco Moreira com uma visão mais clássica e muito relevante, especialmente ao tocar na importância e na pouca valorização ou conhecimento que o público tem de Cecim e de suas obras, e Felipe Pamplona, que trouxe ao documentário uma visão mais atual, mais contemporânea das obras de Cecim, uma fala mais jovial e que não apenas representa, como será identificada pela nova geração. Além destas duas entrevistas também acrescentei imagens de arquivos, pequenos trechos dos filmes dos anos 70, de Vicente Cecim, para que o público que venha a assistir ao documentário conheça um pouco do cinema dele, e que isto aguce a curiosidade deles em conhecer um pouco mais sobre o artista e suas obras.

O documentário agora conta com 4 entrevistas, a do próprio artista que fala sobre suas experimentações, vivências, processos, pontos de vista e visão de mundo, a de Paes Loureiro com o viés acadêmico e as de Marco Moreira e Felipe Pamplona que contribuem com as suas considerações sobre o artista e suas obras, as 4 entrevistas foram montadas de forma menos acadêmica, pois ora apresentam o artista, ora falam sobre ele, e ora complementam as suas ideias. Além das falas dos entrevistados serem algumas vezes justapostas as imagens de arquivo das obras de Cecim, que foram inseridas na nova montagem. Esta nova concepção da obra e montagem tem como objetivo fornecer mais ritmo, 
deixá-lo mais ágil, mais atrativo ao espectador e menos parecido com um aula. A ideia é despertar interesse do espectador em conhecer o artista e ouvir o que ele e as pessoas têm a dizer sobre o próprio, suas obras e seu trajeto. Deixar de ser um vídeo que acompanha uma pesquisa de mestrado para se tornar uma obra cinematográfica, que possua linguagem e estética cinematográfica. Além disso, o documentário ganhou o título A caméra-stylo de Vicente F. Cecim, expressão que faz referência a uma fala sua, dita durante a entrevista, assim como refere-se ao fato dele além de ser cineasta, também ser um escritor.

Por fim, termino este artigo com uma mensagem de Coutinho, que traz o maior desejo do realizador, do artista, do cineasta, logo que também expressa a minha vontade.

Pois o que interessa ao cineasta é pensar de que forma é possível continuar filmando hoje, apesar de tudo, com todas as dificuldades, falta de dinheiro, o estado do mundo, a banalização das estéticas e os riscos de ver esgotadas suas próprias opções de filmagem. O que o interessa é o presente de seus filmes, de seus personagens, o presente do mundo - não o presente instantâneo das imagens televisivas, mas um presente denso de memória e devires possíveis. (Lins, 2004: 10).

\section{Referências Bibliográficas}

Aumont, J. (2012). As teorias dos cineastas. $3^{\mathrm{a}}$ ed. Campinas: Papirus.

Cecim, V. (s.d.). Entrevista de Autor. Belém. Vídeo. Belém.

Freire, M. (2011). Documentário - ética, estética e formas de representação. São Paulo: AnnaBlume.

Lins, C. (2004). O documentário de Eduardo Coutinho: televisão, cinema e vídeo. Rio de Janeiro: Jorge Zahar Editor Ltda.

Nichols, B. (2016). Introdução ao documentário. $6^{\mathrm{a}}$ ed. Campinas: Papirus.

Xavier, I. (2003). A experiência do cinema. $3^{\mathrm{a}}$ ed. Rio de Janeiro: Graal. 


\section{Anexos}
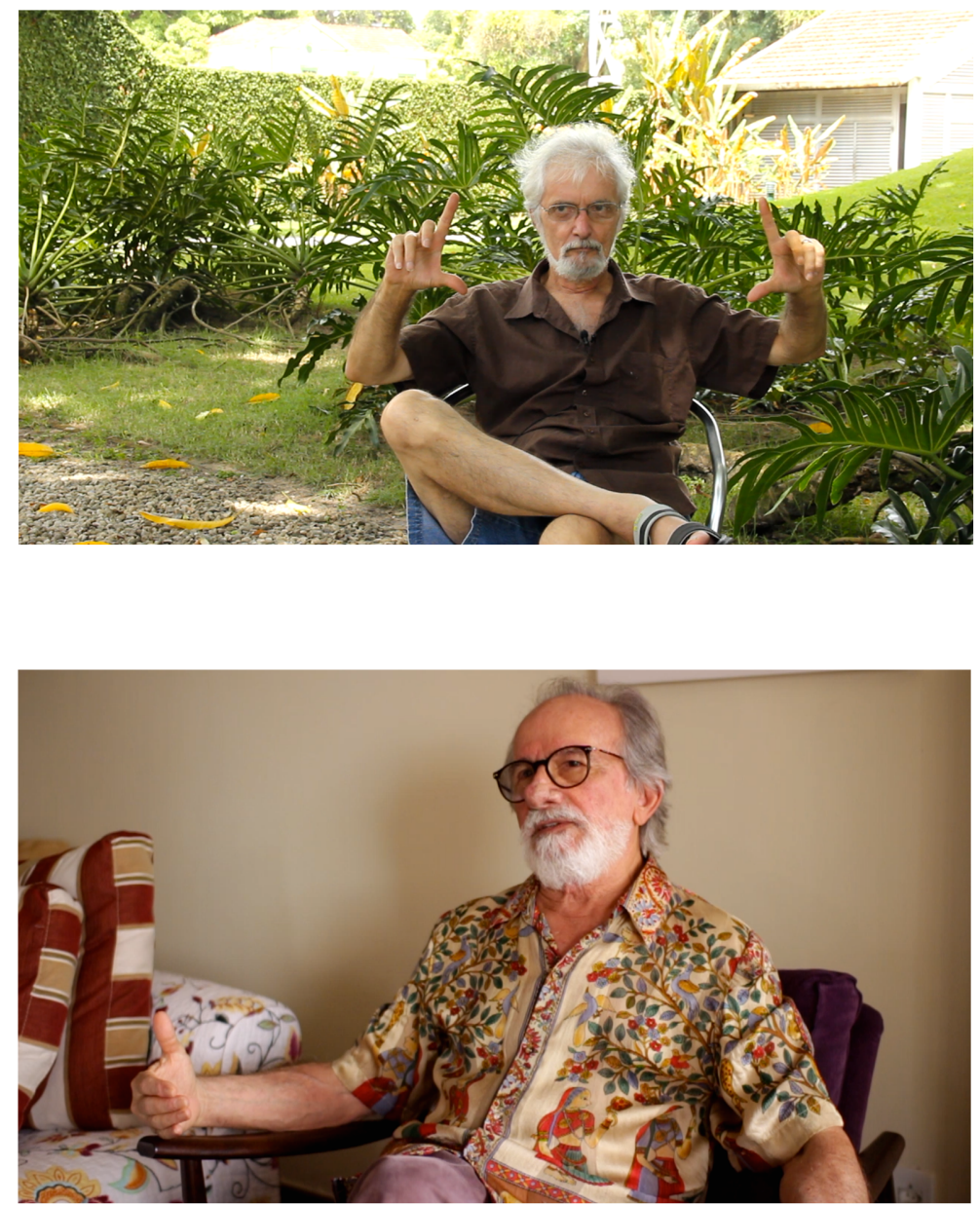

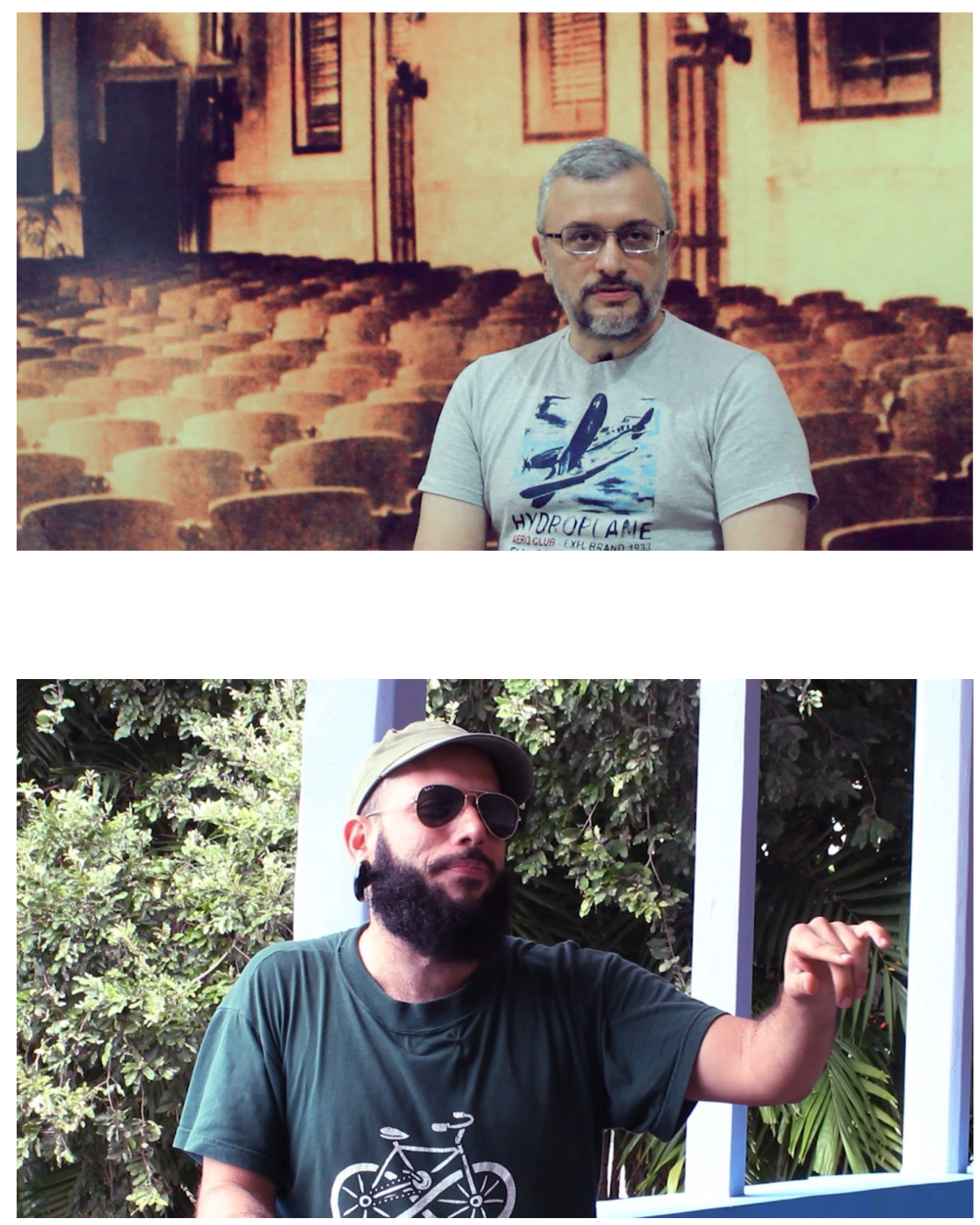

Still's do Filme Caméra-stylo de Vicente F. Cecim (2108), de Alexandra Castro - Digital. 